\title{
The economic development of regions in Ukraine: with tests on the territorial capital approach
}

\author{
Michael Getzner $^{1}$ (D) Serhiy Moroz $^{2}$ (D)
}

Accepted: 29 July 2021 / Published online: 16 September 2021

(c) The Author(s) 2021

\begin{abstract}
The territorial capital approach is used to investigate the economic development of regions in Ukraine in an empirical model. In addition to 'traditional' models of regional development, potentially important variables for economic growth, such as elements of social and societal capital (e.g., trust, corruption, non-profit organizations, libraries), are included. Furthermore, the effects of the military conflicts in Ukraine on regional development are described. The empirical results suggest thatwhile there are no clear-cut effects of all elements of the territorial capital-some interesting variables are of significant importance for the regional development in Ukraine. For instance, strengthening the cultural and social, as well as institutional capital as parts of the overall governance structure, may have positive effects on regional development equal to those originating from hard infrastructure, such as roads and railroads. The results also indicate that-besides the devastating effects of the military conflicts-there is a range of options for public policies supporting territorial capital. These policies include the provision and implementation of robust legal frameworks to increase trust and to reduce corruption, the support of educational efforts and the institutions of civil society, and the promotion of local (i.e. municipal) investments in the framework of a foundational economy.
\end{abstract}

Keywords Economic/regional development · Ukraine · Territorial capital · Economic growth

Responsible Editor: Fritz Breuss.

Michael Getzner

michael.getzner@tuwien.ac.at

Serhiy Moroz

smorozmail@gmail.com

1 Institute of Spatial Planning, Department of Public Finance and Infrastructure Policy, Vienna University of Technology (TU Wien), Karlsplatz 13, 1040 Vienna, Austria

2 Faculty of Economics and Management, Department of Marketing and Trade, Slovak University of Agriculture in Nitra, Tr. A. Hlinku 2, 94976 Nitra, Slovakia 
JEL Classification R11 $\cdot$ R15 $\cdot$ R58 $\cdot$ H54

\section{Introduction and background}

There is a long debate on the determinants of regional economic and social development as numerous theories and models are still turning up. In recent years, the concept of territorial capital has gained importance in analyzing regional development (e.g., Benassi et al. 2021; Fratesi and Perucca 2019, 2020; Morretta 2021; Romão and Neuts 2017). The basic idea behind the concept is that the standard assumptions about the importance of, for instance, productive capital, human capital, accessibility, infrastructure, and land, are complemented by indicators describing social capital (e.g., existence of local libraries), innovativeness (e.g., patents), and societal aspects such as trust, corruption, and intensity of social relations.

According to Camagni and Capello (2008), territorial capital considers the impacts of different factors on territorial assets: tangible goods, intangible goods and mixed goods (see also Camagni 2008). The researchers argue that the main function of capital is, in general, to improve the efficiency and productivity of economic activities at the local level. In this sense, the territorial capital approach is focused on the supply-side of the economy, contrary to Keynesian models that put their emphasis on aggregate demand (cf. Camagni 2008). The latter might be justified for predicting the development of a country's entire economy, but clearly has limits in regard to local and/or regional economies. As Capello (2007) argues, the territorial capital approach is not only useful to statically ascertain the potential determinants of regional development-eventually to suggest economic policies in order to support the productive capacity and innovativity of a region-but also to forecast dynamically the regional economic development.

Empirically, the concept makes use of a much broader data base than other approaches by including several elements of 'capital' that are often not easily commensurable, or are not regularly reported in the national accounting systems on a regular (e.g., annual) basis for regions or territories.

Tóth (2017) points out that territorial capital is a broad consideration and integration of local (endogenous) resources which could be used effectively in order to enhance regional competitiveness. The author emphasizes that the territorial capital concept, while conceptually well-defined, is also a broad concept that has to be made operational for an empirical test. Camagni and Capello (2008) identify the following elements of territorial capital that account for the macroeconomic, institutional, and socio-economic and demographic driving forces for analyzing and predicting regional development (Capello 2007):

- Public goods and services;

- intermediate, mixed-rivalry tangible goods;

- private fixed capital and toll goods;

- social capital;

- relational capital;

- human capital; 
- agglomeration economics, connectivity and receptivity;

- co-operation networks; and

- relational private services.

The territorial capital approach has been used for a limited variety of regions and countries. However, there are only a few papers on the empirical validity of the territorial capital approach for Central and Eastern European transition countries. Notable exceptions include Tóth (2017) and Jóna (2015a) for Hungary (see Sect. 2). In regard to the regional development in Ukraine, no such studies are available. While the lack of studies for Ukraine is an important motivation of this paper by itself, the regional development in Ukraine is an especially interesting case study. First, the ongoing military conflicts and the occupation of Ukrainian territory by Russia that led to sanctions of the European Union (Council of the European Union 2020) poses economic hardship to the neighboring regions. Second, Ukraine has undertaken efforts for a closer political and economic cooperation with the European Union. However, critics have argued that weak institutions and governance, and corruption are still serious problems. Therefore, this paper specifically addresses the growth differences between regions in Ukraine owing to weak governance and the military conflicts in the framework of the territorial capital concept.

The aim of this paper is thus to investigate the determinants of regional economic development of the Ukrainian regions in this framework. The validity of the territorial capital concept is tested in a panel setting, with 27 Ukrainian administrative regions (25 oblasts, Autonomous Republic of Crimea, and two cities with special status: Kyiv and Sevastopol) and over a period of observation from 2003 to 2018 (for the Autonomous Republic of Crimea and city of Sevastopol, data are available from 2003 to 2013). The following research questions are dealt with:

- Which variables of the territorial capital concepts determine the development of the regions in Ukraine?

- How do variables associated with institutions and governance frameworks, such as corruption, affect regional development?

The results of this paper infer that some of the key variables of the territorial capital theory do indeed explain the economic development of regions in Ukraine. However, the changing size and significance of the coefficients in the econometric estimations infer that there is no clear-cut explanation for the different developments of the economies in the various regions. However, elements of the social and institutional capital seem to be important predictors of regional development in Ukraine. For instance, lower crime rates are clearly beneficial for regional development.

The structure of the paper is as follows: A brief literature review on empirical tests of the territorial capital approach is presented in Sect. 2. Descriptive and econometric results are presented and discussed in Sect. 3, while in Sect. 4, the results are summarized and conclusions are drawn. 


\section{Empirical evidence on the territorial capital approach: a short overview}

It should be noted that there are many publications devoted to the study of the concept of territorial capital and of the peculiarities of its influence on regional development. This brief literature review deals with empirical studies on the territorial capital approach, and starts out with some papers dealing with European regions in different countries, before reviewing studies on Italian regions. Central and Eastern European countries are included afterwards.

However, empirical studies that investigate the significance of the territorial capital approach in Central and Eastern Europe are rare. On a broader European level, Fratesi and Perucca (2019) explored the influence of territorial capital on the economic growth of EU15 regions in the context of the European Union's cohesion policies. Based on the analysis, the authors find that some forms of capital that are exclusive to the territorial capital approach have had a positive impact on the socio-economic state of regions. They also emphasize the complementary linkages between territorial capital and regional policy, which is important for regions with different levels of economic development (see also Fratesi and Perucca 2014; Bachtrögler et al. 2019).

In regard to economic shocks, Fratesi and Perucca $(2019,2020)$ analyzed the role of territorial capital for the resilience of EU regions to cope with the economic crisis that emerged in 2007 and 2008. For this purpose, groups of regions are identified, depending on the intial endowments of territorial capital. The authors find that the resilience of the regions in regard to contractive economic shocks correlates substantially with the available territorial assets.

In some studies, the development and impact of territorial capital might be observed in different directions, depending on the countries, regions, and periods investigated. For example, Romão and Neuts (2017) ascertained the effects of territorial capital, local resources, and tourism specialization, on the sustainable development of selected European regions. The results show that unfavorable socio-economic tendencies might take place in regions with rich natural resources and a specialized tourism sector. The main reason for the weak regional performance is the emphasis the tourism sector places on mass consumer products and services, which have in addition also low value. Therefore, for a correct assessment of the situation, it is necessary to take into account not only quantitative, but also qualitative characteristics of territorial capital.

Many single-country papers prominently focus on Italian regions. Lo Cascio et al. (2019) examined the effects of several forms of assets related to the territorial capital on the economic state of Italian provinces from 1999 to 2014. By applying a spatial Durbin model, the authors discover that the majority of the chosen variables exhibits positive effects on the economic development at the regional level. However, these effects seem to be somewhat different before and during the periods of crisis.

In regard to the asymmetric effects of territorial capital, Mazzola et al. (2018) investigated the influence of various components of territorial capital on the 
economic growth of Italian provinces before and after periods of crises (for local Italian growth, see also Perucca 2014). While human capital has a strong impact on the economic performance at the regional level during crisis and non-crisis periods, cultural and natural capital play an essential role on a few indicators (GDP and export growth) in the period of a crisis. Other components of territorial capital affect the economic growth of provinces only when not in the periods of crises.

Barzotto et al. (2016) investigated how essential the territorial capital approach is in terms of the location and the effective operation of Italian multinational corporations. The results indicate that the territorial capital positively affects the values and performances of the companies by making a significant contribution to their longterm rise and recognition worldwide.

In regard to studies on Eastern European countries, Jóna (2015a) analyzed various factors that influence the increase of the territorial capital of Hungarian subregions. While socio-economic proximity has a strong effect on the accumulation of territorial capital, socio-cultural proximity in particular creates conditions for its more stable accumulation. In order to ensure the effective accumulation of this form of capital, the paper stresses that a close co-ordination between the regional economic actors and the network structure's capacities is necessary.

Fábián and Tóth (2014) placed their research focus on cultural capital as an important element of territorial capital, by using data on Hungarian micro-regions. Employing multivariate statistical methods, the researchers distinguished several types of regions by investigating various cultural attributes. Taking into account these regional differences, the empirical investigation confirms that the cultural characteristics of micro-regions affect the economic development of these regions.

Dodescu et al. (2018) examined the effects of the different forms of territorial capital on the economic performance of Romanian counties. Based on structural equation modeling, the results indicate that the elements of territorial capital do not have an equal effect on regional development. While economic and infrastructure capital contribute to Romania's regional growth, human and institutional capital have only a limited influence on the economic growth of Romanian counties. Interestingly, social capital is negatively correlated with their economic performance.

In another Hungarian paper, Jóna (2015b) took into consideration the peculiarities of the rapid growth of territorial capital and its influence on the state of the economy of Hungarian micro-regions during the period from 2004 until 2010. By applying spatial econometrics, the author found that the rapid increase of territorial capital causes negative changes at the country's regional level. Besides, such excessive growth reduces the effects of infrastructural capital and social capital.

In regard to this paper, the brief literature review revealed that there are various studies that confirm the usefulness of the territorial capital approach for analyzing regional economic development. However, there are also clear limitations to this approach since the empirical literature is somewhat ambiguous in regard to the significance and the direction of influence of the different forms of territorial capital on the regional development. More specifically, while the papers reviewed here all consider the territorial capital approach to be useful, the empirical applications as well as methods and countries are hugely diverse. This is mostly due to the lack of 
consistent data, which is of particular significance in transition countries (see also Sect. 3.1). Furthermore, most studies including this paper use a structural equation estimation of a regional growth or development model (e.g., production function approach), while other possible approaches include, e.g., more data driven methods such as simultanous equations, or VAR (vector autoregression) and VEC (vector error-correction) models. In regard to transition countries, a further limitation is also the availability of robust economic and social data. As will be described below, high inflation rates, and a potentially large shadow economy, pose specific problems. This paper utilizes the best available data provided by the State Statistics Service of Ukraine. However, the limitations of data reliability could not be solved in this paper. In order to provide results as robust as possible, the paper presents various specifications of the estimation, and two types of panel estimations (fixed and random effects).

Concludingly, only a few European countries and regions have been studied within this framework so far. The following sections provide an empirical assessment of the influence of territorial capital on regional development in Ukraine.

\section{Descriptive and econometric results}

\subsection{Descriptive results}

The territorial capital approach, as reviewed in Sect. 2, includes a broad range of elements and methods (e.g., infrastructure, social/cultural capital) to describe and analyze the economic development of regions. The regional per-capita GDP (GRP, Gross Regional Product), the regional economic growth (measured as the growth rate of GRP at constant prices), and the employment ratio (total employment as a ratio to the regional population) are included as dependent variables in the statistical analysis. Table 1 contains a short description of the variables used in the estimations, and a column denoting the expected sign of the coefficient in the estimations (serving as the respective baseline hypotheses). The explanatory variables include, on the one hand, control variables denoting the size of the population, population density, and regional exports of goods to other countries.

On the other hand, for the study of regions in Ukraine, six different categories of the territorial capital are used, based on the review of papers in Sect. 2, as well as the elements of the territorial capital concept presented above (e.g., Capello 2007). However, owing to the limitations in regard to the availability of data, the various dimensions (elements) of territorial capital had to made operational by a limitied number of variables. The dimensions of territorial capital are labelled according to, e.g., Tóth (2017). (1) The public capital (transport infrastructure) is approximated and made operational by means of the density of roads and railtracks (length of infrastructure per square $\mathrm{km}$ ). Of course, the public capital includes other forms of capital as well besides transportation infrastructure. However, data on energy, telecommunication, and utilities are not available on the regional level in a standardized form for the observation period of this paper. (2) The cultural capital includes heterogenous variables, such as the number of 


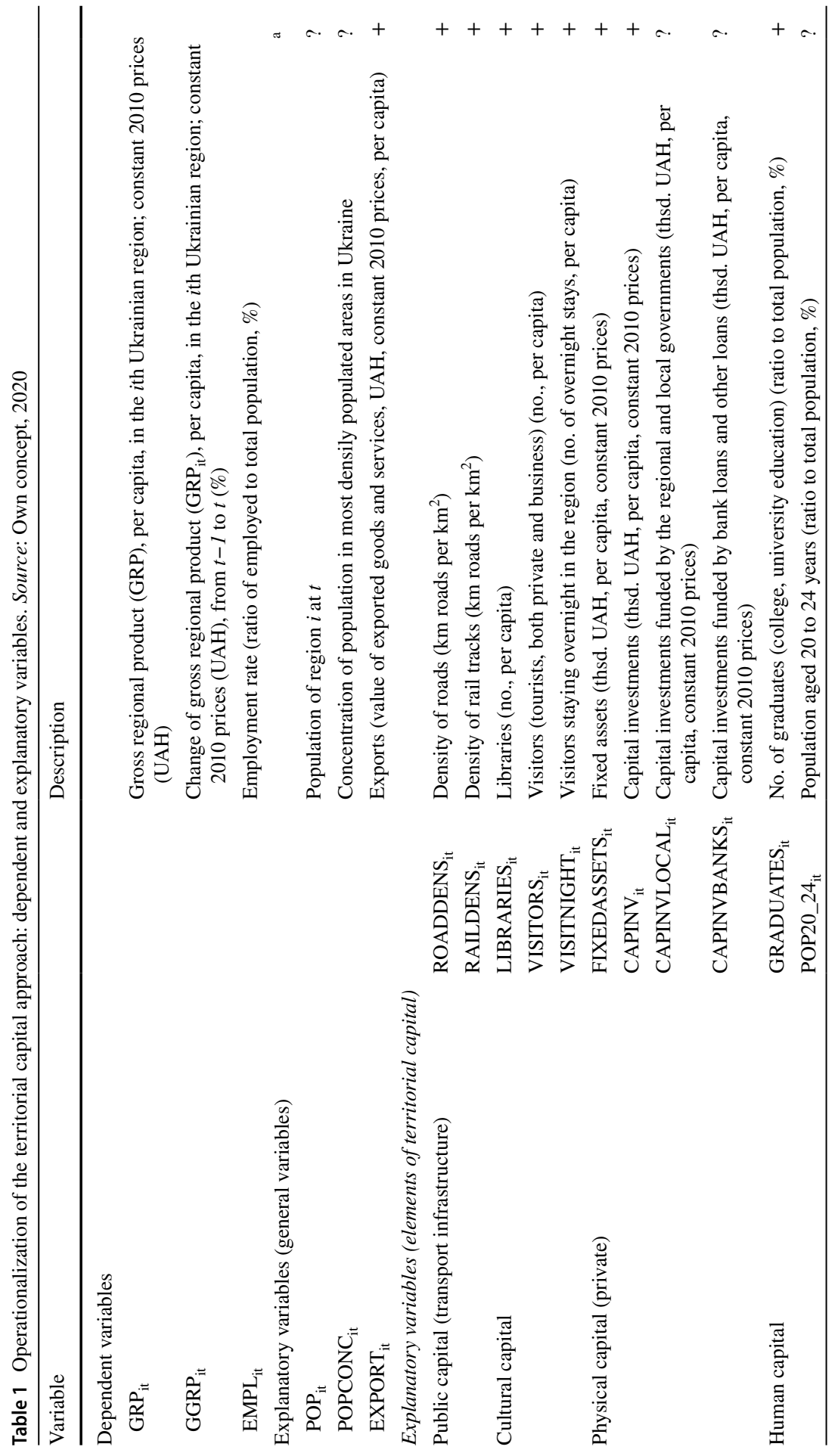




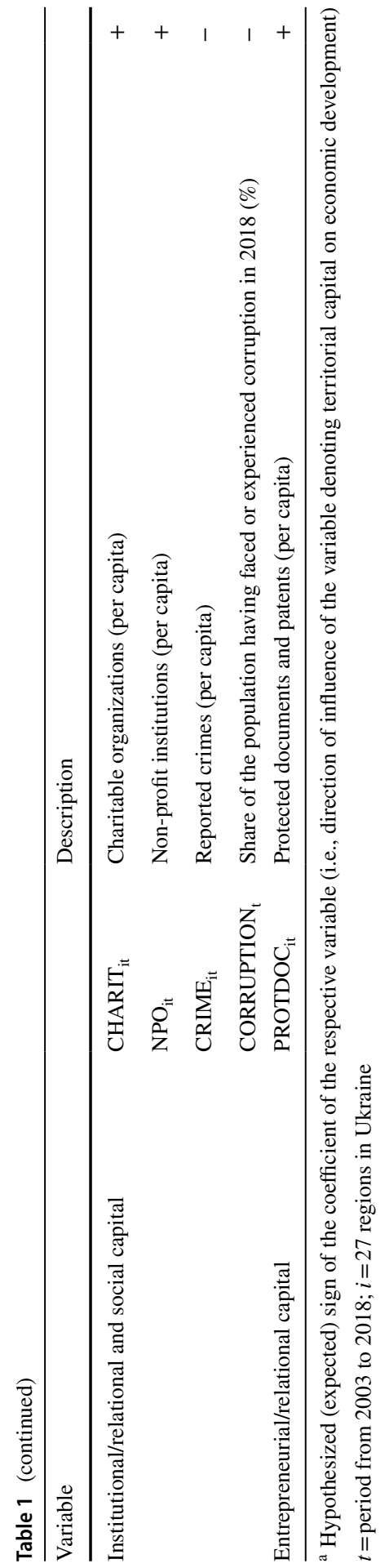


libraries, visitors, and overnight stays. (Unfortunately, other variables denoting cultural capital could not made operational for this paper). (3) The (private) physical capital is denoted by the stock of capital, i.e., fixed assets (e.g., machinery), and by the amount of capital invested. The means of the funding of investments include the financing by bank loans and local/regional governments, alternative to financial commitments by the central government and international investors. (4) The variables denoting human capital include the age distribution of the population in a simplified version (i.e., the ratio of adults aged 20-24 to the total population), and the number of graduates of colleges and universities. (5) The institutional capital (governance) includes the number of charities and non-profit organizations, as well as reported cases of crime, and corruption as perceived by citizens. (The latter variable is not available on a regional level, while data is available for each year of the observation period for the whole of Ukraine). (6) The extent to which intellectual property may play a role in regional development is operationalized by the number of protected documents (e.g., patents) as part of the entrepreneurial and relational capital.

The six forms of capital are regarded as important parts of the territorial capital of the respective Ukrainian regions. The choice of the (operational) variables to be accounted for in the econometric estimations is varied in the scientific literature. For instance, Mazzola et al. (2018) included a variable denoting the accessibility to the local and regional labor markets as an element of territorial capital (labeled public capital in this paper) in their study on Italian regions. The availability of regional data often restricts the use of more comprehensive and detailed information. However, in this paper, the number of NGOs and perceived corruption are used as additional variables that are not included in the study by Mazzola et al. (2018). The paper written by Fratesi and Perucca (2019) also includes several variables that are not included in this paper. For instance, the authors account for the number of IP addresses as an element of private capital. Again, this paper includes fixed assets and the number of graduates. In turn, these variables are not included by Fratesi and Perucca (2019) in their paper. It seems that the empirical literature that takes up the territorial capital approach is not consistent in accounting for all of the possible elements of the territorial capital which, as originally developed by Camagni (2008), is often and mostly owing to data problems and lack of standardization of the various elements of the territorial capital.

Data problems are particularly serious in transition countries, as data are often missing due to a short observation period or breaks in the time series or relevant variables (cf. Weyerstrass 2008; Weyerstrass et al. 2001; Welfe 2013; Getzner and Moroz 2020). In addition, Ukraine suffers from the annexation and occupation of Crimea and the Eastern provinces (regions) by Russian forces, as well as from the ongoing armed conflicts.

From an empirical point of view, this paper uses a common specification of models linking the regional performance variables $\left(y_{i t}\right)$ to a vector of explanatory variables $\left(x_{i t}\right)$. Following the denotion of Mazzola et al. (2018), the specification of the fixed effects model to be estimated is: 


$$
y_{i t}=\gamma_{i}+\beta x_{i t-1}+\eta_{i},
$$

with $\gamma_{i}$ denoting the fixed effects specific to each region, and $\eta_{i}$ the error term. For the random effects model, $\gamma_{i}$ is replaced by $\delta_{i}=\lambda+\gamma_{i}$, where $\gamma_{i}$ is a stochastic variable (with zero mean, constant variance, and no correlation with the error term). $\beta$ denotes the parameters to be estimated, and $x_{i t-1}$ are the explanatory variables (forms of territorial capital described above and in Table 1).

The model specification of Eq. (1) assumes that changes of the explanatory variables do not immediately influence the dependent variables (e.g., economic growth), but that there is a lag of 1 year. It has to be noted further that all the variables (except the variables denoted in percentages) are included in their natural logs. As the data are drawn from heterogenous regions, the Eq. (1) is estimated in a panel setting using both the longitudinal as well as the cross-section characteristics of the data, correcting for heteroscedasticity by cross-section weights. The lag length was tested in several specifications, and a short lag length resulted in the best statistical fit. However, increasing the lag length transforms the estimations rather to a crosssectional analysis than a panel data set-up.

The paper is based on data and publications available from the State Statistics Service of Ukraine and its website (www.ukrstat.gov.ua). The data on 27 Ukrainian regions are normalized in order to take into consideration the size of the regions, and they are also adjusted for inflation (on the basis of the GDP deflator) that changed substantially during the observation period, which was from 2003 to 2018. For the 2014-2018 period, the data on the temporarily occupied territories of the Autonomous Republic of Crimea and Sevastopol (city) were and still are not available. Data on the Donetsk and Luhansk regions are available for enterprises, institutions and organizations which submitted reports to the state statistics bodies regarding the same period of time. Regional data on corruption are used from the USAID/ ENGAGE anti-corruption poll (Ilko Kucheriv Democratic Initiatives foundation 2018).

Figure 1 contains an overview of the per-capita GRP in regions of Ukraine at current prices (2017). The mean GDP per capita in Ukraine amounts to approx. UAH 70,000 (corresponding to approx. USD 2500). However, some regions have a significantly higher per-capita income than others (see Fig. 1).

Figure 2 presents data on GRP per capita at current prices in 2017, calculated as the deviation from the Ukrainian mean of UAH 70,000 per capita. It should be noted that the highest level of this indicator was observed in the capital city of Ukraine, Kyiv (339.8\% of the Ukrainian GDP), followed by Poltava oblast (151.3\%) and Dnipropetrovsk oblast (138.3\%). Also, this indicator was higher than the country's average in Kyiv oblast (128.2\%) and Zaporizhzhya oblast (107.2\%). These regions are in the leading position in the country's economic development, demonstrating the developed industrial production, sectoral diversification and a large service sector. Furthermore, these data reveal the great regional disparities in Ukraine in regard to per-capita income. It is noteworthy that there does not seem to be a significant spatial correlation among regions, since some regions with a high GRP have neighbouring regions with a below-average GRP, while the other regions have a quite similar GRP to that of their neighbours. 


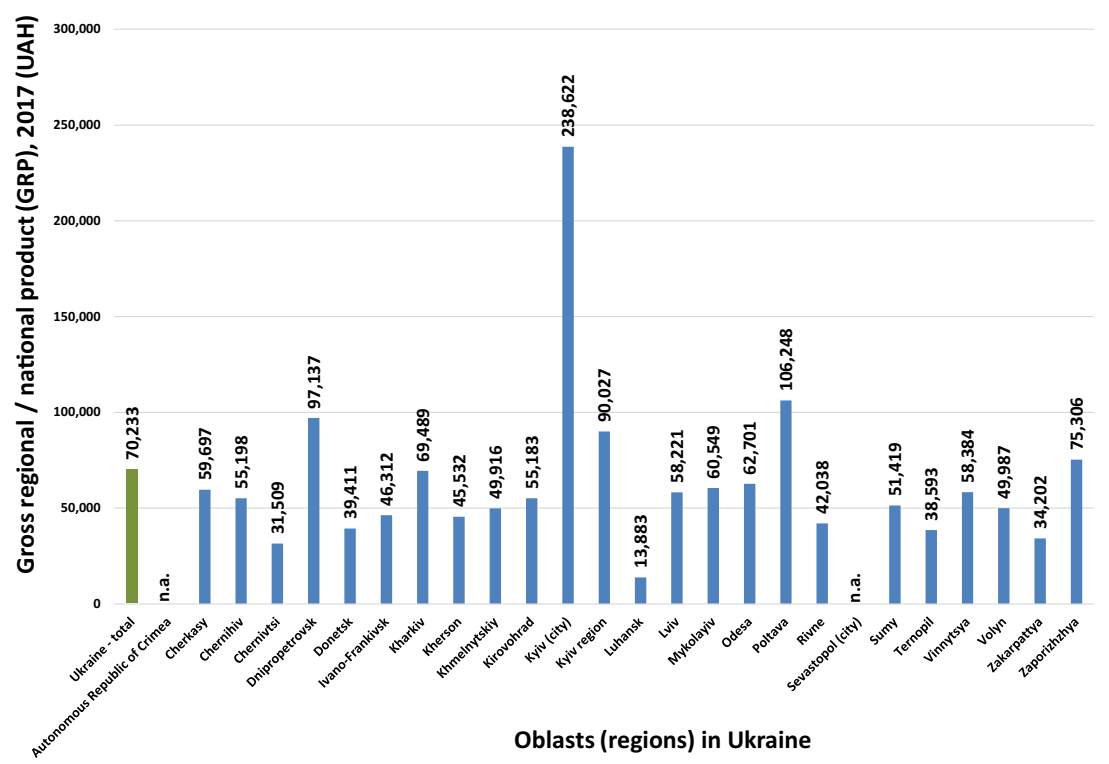

Fig. 1 Gross regional (national) product, per capita, 2017 (current prices). Source: Own draft and calculations based on data from the State Statistics Service of Ukraine

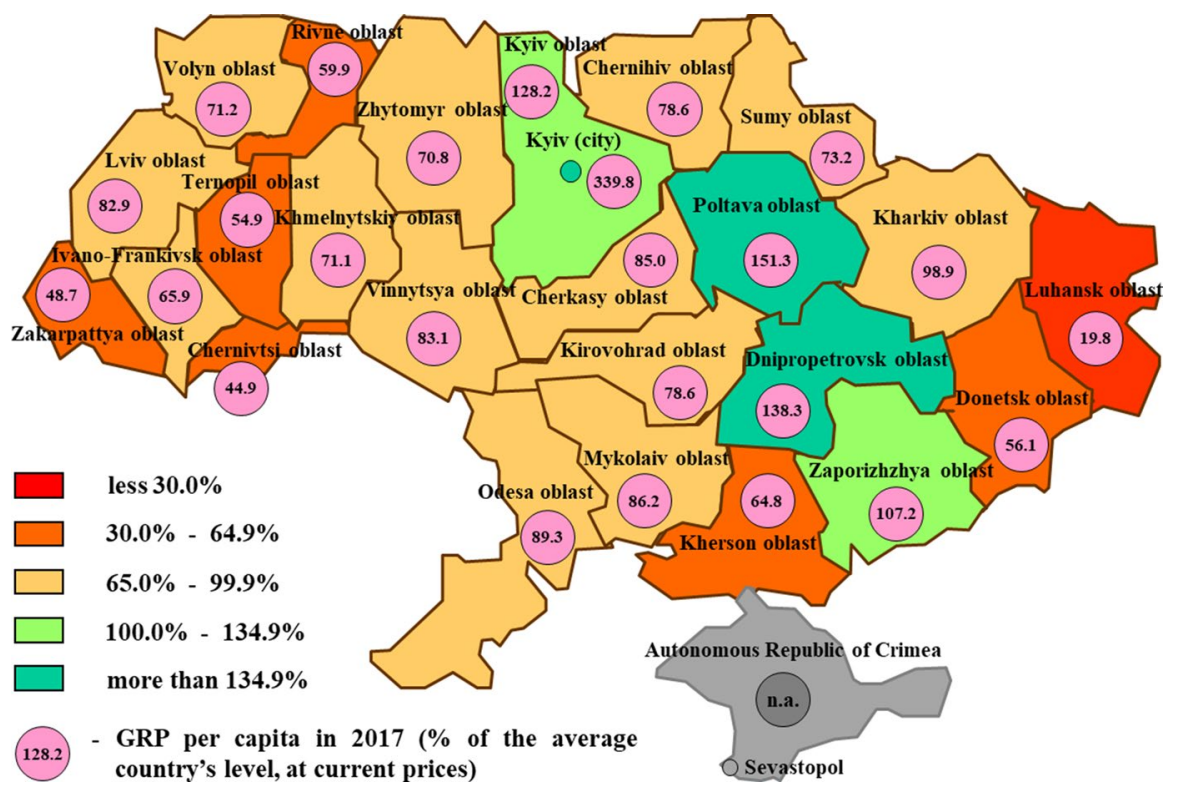

Fig. 2 GRP per capita in 2017 (\% of the average country's level, at current prices). Source: Own draft and calculations based on data from the State Statistics Service of Ukraine 


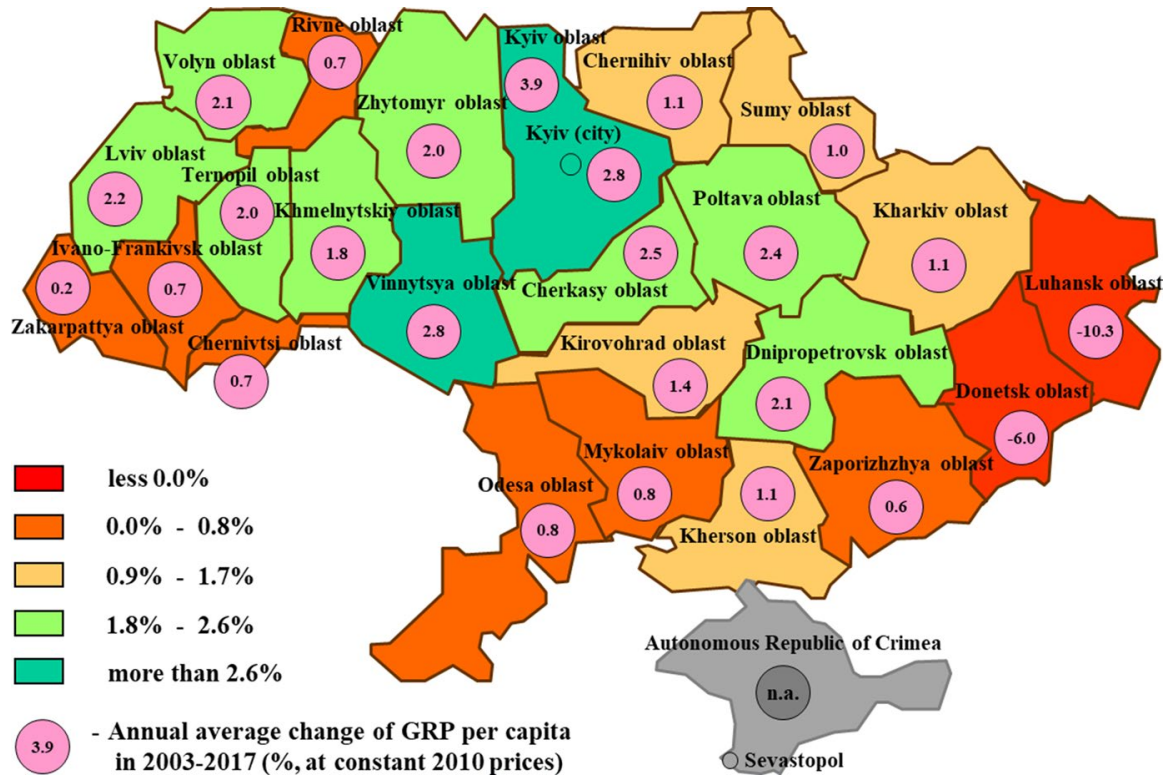

Fig. 3 Economic growth of regions in Ukraine (annual average change of GRP per capita from 2003 to $2017, \%$, at constant 2010 prices). Source: Own draft and calculations based on data from the State Statistics Service of Ukraine

For all the other regions, this indicator was below its national average. Its minimum value was observed in Luhansk oblast (19.8\%) as a result of the ongoing military conflict, significant destruction of the region's economic infrastructure and the occupation by pro-Russian forces. The available data indicate that many regions with a below-average income are also located in the Western parts of Ukraine, including, for instance, Chernivtsi oblast (44.9\%), Zakarpattya oblast (48.7\%), and Ternopil oblast $(54.9 \%)$. Historically, this situation can be explained by a less efficient industrial sector, as well as the constant migration of the skilled working-age population to other countries. While the low indicator's rate in Donetsk oblast $(56.1 \%)$ can be explained by the same reasons as for Luhansk oblast (the military conflict, destruction of the region's economy, and its partial occupation by pro-Russian forces), economic development of Kherson oblast (64.8\%) was substantially limited due to its border with the Russian-occupied Crimean Peninsula.

The annual average changes of GRP per capita (at constant 2010 prices) in the period from 2003 to 2017 are given in Fig. 3. The highest economic growth was observed in Kyiv oblast, Kyiv (the capital city of Ukraine), and Vinnytsya oblast, for which the indicator's values were $3.9 \%, 2.8 \%$, and $2.8 \%$, respectively. In the Eastern and Western parts of Ukraine, several regions also experienced a continuous economic growth over the observation period, namely, Cherkasy oblast (2.5\%), Poltava oblast $(2.4 \%)$, and Dnipropetrovsk oblast $(2.1 \%)$ in the East, and Zhytomyr oblast (2.0\%), Ternopil oblast (2.0\%), and Khmelnytskiy oblast (1.8\%), as well as the two regions bordering the European Union, Lviv oblast (2.2\%) and Volyn oblast (2.1\%) in the West. 
Table 2 Panel unit-root tests (variable: $\mathrm{GRP}_{\mathrm{it}}$ ). Source: Own calculations, 2019

\begin{tabular}{|c|c|c|c|c|c|c|}
\hline & \multicolumn{4}{|l|}{ Levels } & \multirow{2}{*}{\multicolumn{2}{|c|}{$\frac{1 \text { st difference }}{\text { Individual effects }}$}} \\
\hline & \multicolumn{2}{|c|}{ Individual effects } & \multicolumn{2}{|c|}{$\begin{array}{l}\text { Individual effects, } \\
\text { individual linear trends }\end{array}$} & & \\
\hline & Statistic & Prob & Statistic & Prob & Statistic & Prob \\
\hline \multicolumn{7}{|c|}{ Common unit root processes assumed } \\
\hline Levin, Lin \& Chu $\mathrm{t}^{*}$ & -6.411 & 0.000 & -8.200 & 0.000 & -18.489 & 0.000 \\
\hline Breitung $t$-stat & & & -1.336 & 0.091 & & \\
\hline \multicolumn{7}{|c|}{ Individual unit root processes assumed } \\
\hline Im, Pesaran \& Shin W-stat & -3.830 & 0.000 & -2.103 & 0.018 & 344.929 & 0.000 \\
\hline ADF_-Fisher Chi-square & 98.410 & 0.000 & 71.515 & 0.056 & 369.277 & 0.000 \\
\hline $\mathrm{PP}$-Fisher Chi-square & 133.180 & 0.000 & 135.161 & 0.000 & & \\
\hline Period & \multicolumn{4}{|c|}{ 2003-2018 } & & \\
\hline$n$ (observations) & \multicolumn{2}{|l|}{343} & & & \multicolumn{2}{|l|}{316} \\
\hline$N$ (cross sections) & \multicolumn{4}{|l|}{27} & & \\
\hline
\end{tabular}

$\mathrm{H}_{0}$ : unit-root

For the Luhansk (-10.3\%) and Donetsk oblasts (-6.0\%), instead of an increase, the GRP growth rate dropped to a negative value corresponding to a significant economic contraction as a consequence of the military conflicts and the destruction of the regions' economic infrastructures. The rather low growth rates of GRP per capita in some Southern regions (Zaporizhzhya, Odesa, and Mykolaiv oblasts) may also be linked to their proximity to the occupied Crimean Peninsula and the consequent need for the economic reorientation of these regions and towns. In general, the average growth rates have to be interpreted with caution, since the Ukrainian economy has experienced significant short-term upward and downward trends, especially following the 2008/2009 economic and financial crisis. Furthermore, average rates do not account for the substantial spatial disparities between regions.

\subsection{Econometric results}

\subsubsection{Testing the characteristics of the relevant panel time series}

The empirical estimation of Eq. (1) described above is based on a range of assumptions. For instance, the analysis of the time series, in general, requires the individual data to be stationary (i.e., mean-reverting), or otherwise to be co-integrated with potential explanatory variables. As a first step of the econometric analysis of this paper, the characteristics of the time series of the variables are explored by means of panel unit-root tests.

Table 2 presents the results of a panel stationarity test of the first dependent variable, per-capita gross regional product $\left(\mathrm{GRP}_{\mathrm{it}}\right)$. The results of the descriptive and graphical analysis in Sect. 3.1 are confirmed by the unit-root tests, because the various test statistics clearly indicate there is a stationary time series, as the hypothesis of the existence of a unit root is rejected $\left(\mathrm{H}_{0}\right.$ : unit root). 
Table 3 Panel unit-root tests (variable: $\mathrm{GGRP}_{\mathrm{it}}$ ). Source: Own calculations, 2019

\begin{tabular}{|c|c|c|c|c|c|c|}
\hline & \multicolumn{4}{|l|}{ Levels } & \multirow{2}{*}{\multicolumn{2}{|c|}{$\frac{1 \text { st difference }}{\text { Individual effects }}$}} \\
\hline & \multicolumn{2}{|c|}{ Individual effects } & \multicolumn{2}{|c|}{$\begin{array}{l}\text { Individual effects, indi- } \\
\text { vidual linear trends }\end{array}$} & & \\
\hline & Statistic & Prob & Statistic & Prob & Statistic & Prob \\
\hline \multicolumn{7}{|c|}{ Common unit root processes assumed } \\
\hline Levin, Lin \& Chu $t^{*}$ & -17.114 & 0.000 & -15.817 & 0.000 & -28.436 & 0.000 \\
\hline Breitung $t$-stat & & & -5.998 & 0.000 & & \\
\hline \multicolumn{7}{|c|}{ Individual unit root processes assumed } \\
\hline Im, Pesaran \& Shin W-stat & -11.536 & 0.000 & -6.689 & 0.000 & & \\
\hline ADF_Fisher Chi-square & 218.908 & 0.000 & 148.835 & 0.000 & 487.142 & 0.000 \\
\hline $\mathrm{PP}$-Fisher Chi-square & 304.109 & 0.000 & 265.257 & 0.000 & 523.306 & 0.000 \\
\hline Period & \multicolumn{6}{|c|}{ 2003-2018 } \\
\hline$n$ (observations) & \multicolumn{4}{|l|}{316} & \multicolumn{2}{|l|}{289} \\
\hline$N$ (cross sections) & \multicolumn{4}{|l|}{27} & & \\
\hline
\end{tabular}

$\mathrm{H}_{0}$ : unit-root

Table 4 Panel unit-root tests (variable: $\mathrm{EMPL}_{\mathrm{it}}$ ). Source: Own calculations, 2019

\begin{tabular}{|c|c|c|c|c|c|c|}
\hline & \multicolumn{4}{|l|}{ Levels } & \multirow{2}{*}{\multicolumn{2}{|c|}{$\frac{\text { 1st difference }}{\text { Individual effects }}$}} \\
\hline & \multicolumn{2}{|c|}{ Individual effects } & \multicolumn{2}{|c|}{$\begin{array}{l}\text { Individual effects, indi- } \\
\text { vidual linear trends }\end{array}$} & & \\
\hline & Statistic & Prob & Statistic & Prob & Statistic & Prob \\
\hline \multicolumn{7}{|c|}{ Common unit root processes assumed } \\
\hline Levin, Lin \& Chu $\mathrm{t}^{*}$ & -5.075 & 0.000 & -12.700 & 0.000 & -22.116 & 0.000 \\
\hline Breitung t-stat & & & 1.658 & 0.000 & & \\
\hline \multicolumn{7}{|c|}{ Individual unit root processes assumed } \\
\hline Im, Pesaran \& Shin W-stat & -1.056 & 0.145 & -4.851 & 0.000 & & \\
\hline ADF_Fisher Chi-square & 85.012 & 0.000 & 112.116 & 0.000 & 362.490 & 0.000 \\
\hline $\mathrm{PP}$-Fisher Chi-square & 94.627 & 0.000 & 159.023 & 0.000 & 369.891 & 0.000 \\
\hline Period & \multicolumn{4}{|c|}{$2003-2018$} & & \\
\hline$n$ (observations) & \multicolumn{2}{|l|}{370} & & & \multicolumn{2}{|l|}{343} \\
\hline$N$ (cross sections) & \multicolumn{4}{|l|}{27} & & \\
\hline
\end{tabular}

$\mathrm{H}_{0}$ : unit-root

Similar results can be derived by testing the stationarity of the two other dependent variables, economic growth $\left(\mathrm{GGRP}_{\mathrm{it}}\right)$ and the employment ratio $\left(\mathrm{EMPL}_{\mathrm{it}}\right)$. For both variables, $\mathrm{H}_{0}$ is rejected at any reasonable level of significance, inferring that both time series are integrated of order 1 (Tables 3, 4).

Of the numerous explanatory variables of the territorial capital assumed to influence economic development, ${ }^{1}$ Table 5 presents the panel unit-root tests for the

\footnotetext{
${ }^{1}$ Owing to restrictions of space, only selected tests of stationarity are presented. More information can be sent by the authors upon request.
} 
Table 5 Panel unit-root tests (variable: $\mathrm{POP}_{\mathrm{it}}$ ). Source: Own calculations, 2019

\begin{tabular}{|c|c|c|c|c|c|c|}
\hline & \multicolumn{4}{|l|}{ Levels } & \multirow{2}{*}{\multicolumn{2}{|c|}{$\frac{1 \text { st difference }}{\text { Individual effects }}$}} \\
\hline & \multicolumn{2}{|c|}{ Individual effects } & \multicolumn{2}{|c|}{$\begin{array}{l}\text { Individual effects, indi- } \\
\text { vidual linear trends }\end{array}$} & & \\
\hline & Statistic & Prob & Statistic & Prob & Statistic & Prob \\
\hline \multicolumn{7}{|c|}{ Common unit root processes assumed } \\
\hline Levin, Lin \& Chu $\mathrm{t}^{*}$ & -16.839 & 0.000 & -10.588 & 0.000 & -5.598 & 0.000 \\
\hline Breitung t-stat & & & 9.630 & 0.000 & & \\
\hline \multicolumn{7}{|c|}{ Individual unit root processes assumed } \\
\hline Im, Pesaran \& Shin W-stat & -10.818 & 0.000 & -3.682 & 0.000 & & \\
\hline ADF-Fisher Chi-square & 225.616 & 0.000 & 108.257 & 0.000 & 100.586 & 0.000 \\
\hline $\mathrm{PP}$-Fisher Chi-square & 196.870 & 0.000 & 126.998 & 0.000 & 103.800 & 0.000 \\
\hline Period & \multicolumn{4}{|c|}{ 2003-2018 } & & \\
\hline$n$ (observations) & \multicolumn{2}{|l|}{370} & & & \multicolumn{2}{|l|}{343} \\
\hline$N$ (cross sections) & \multicolumn{4}{|l|}{27} & & \\
\hline
\end{tabular}

$\mathrm{H}_{0}$ : unit-root

Table 6 Panel unit-root tests (variable: EXPORT ${ }_{\text {it }}$ ). Source: Own calculations, 2019

\begin{tabular}{|c|c|c|c|c|c|c|}
\hline & \multicolumn{4}{|l|}{ Levels } & \multirow{2}{*}{\multicolumn{2}{|c|}{$\frac{\text { 1st difference }}{\text { Individual effects }}$}} \\
\hline & \multicolumn{2}{|c|}{ Individual effects } & \multicolumn{2}{|c|}{$\begin{array}{l}\text { Individual effects, } \\
\text { individual linear trends }\end{array}$} & & \\
\hline & Statistic & Prob & Statistic & Prob & Statistic & Prob \\
\hline \multicolumn{7}{|c|}{ Common unit root processes assumed } \\
\hline Levin, Lin \& Chu t* & -1.766 & 0.039 & -7.074 & 0.000 & -18.529 & 0.000 \\
\hline Breitung t-stat & & & -1.066 & 0.143 & & \\
\hline \multicolumn{7}{|c|}{ Individual unit root processes assumed } \\
\hline Im, Pesaran \& Shin W-stat & 0.551 & 0.709 & -1.370 & 0.085 & & \\
\hline ADF_-Fisher Chi-square & 55.267 & 0.427 & 65.279 & 0.140 & 345.609 & 0.000 \\
\hline $\mathrm{PP}$-Fisher Chi-square & 57.850 & 0.335 & 100.539 & 0.000 & 381.631 & 0.000 \\
\hline Period & \multicolumn{4}{|c|}{ 2003-2018 } & & \\
\hline$n$ (observations) & \multicolumn{2}{|l|}{370} & & & \multicolumn{2}{|l|}{343} \\
\hline$N$ (cross sections) & \multicolumn{4}{|l|}{27} & & \\
\hline
\end{tabular}

$\mathrm{H}_{0}$ : unit-root

population of the Ukrainian regions $\left(\mathrm{POP}_{\mathrm{it}}\right)$. The hypothesis $\left(\mathrm{H}_{0}\right)$ of a unit root in the data can clearly be rejected at reasonable levels of significance. Table 6 presents similar tests for (international) exports $\left(\mathrm{EXPORT}_{\mathrm{it}}\right)$. The unit-root tests are inconclusive for the variable in levels, but clearly suggest stationarity in its first difference.

Besides tests on stationarity, selected variables were tested to establish if there was co-integration - the existence thereof facilitates a straightforward estimation of 
the empirical model described above. As one of the various possibilities to check on the existence of co-integration, Table 7 presents a joint panel co-integration test of four main variables hypothesized to form significant parts of a territorial capital model of economic development for the regions in Ukraine. Several test statistics clearly reject $\mathrm{H}_{0}$ of no co-integration, depending on assumptions about the autoregressive processes underlying the time series, and the inclusion of trends in the cointegrating equation.

\subsubsection{Results of the fixed and random effects models}

To estimate the territorial capital model according to Eq. (1), the time series tests of stationarity and co-integration generally indicate that a rather standard econometric approach is reasonable. Table 8 presents a comprehensive territorial capital estimation of two indicators of regional economic development, regional per-capita GRP $\left(\mathrm{GRP}_{\mathrm{it}}\right)$, and economic growth $\left(\mathrm{GGRP}_{\mathrm{it}}\right)$. The estimations for both variables include either fixed or random effects.

The fixed effects estimation presented as Est. 1 in Table 8 first of all shows that $\mathrm{GRP}_{\text {it }}$ differs between regions based on population and the density of the population. It seems that smaller regions (measured by the size of the population) and some cities that have their own constitutional status — ceteris paribus-exhibit a higher GRP. This correlation is highly significant. However, the variable denoting the density of the population is only weakly significant, similar to the the effect of exports on GRP.

Interestingly, the levels of GRP do not seem to be significantly related to physical infrastructure, such as roads and railtracks in this estimation. However, the elements of cultural capital, such as the number of libraries, or the appeal of a region to visitors as an indicator of the attractiveness to tourists enjoying cultural goods and services, among other motives to visit an area, both exhibit a significant and positive influence on GRP. Furthermore, the stock of capital (fixed assets) as part of the (private) physical territorial capital is less determining for economic development than the capital investments (as flows) undertaken in the previous period.

The variables denoting human and institutional capital turn out to be significant explanatory variables as well. On the one hand, regions with a younger population exhibit a higher per-capita GRP. On the other hand, the number of charities and nonprofitmaking organizations are correlated to the gross regional product in interesting ways. If the number of charities is correlated with households having an income above average, the highly positive coefficient can be explained by this connection. Furthermore, in regions with a smaller average income, non-profit organizations are needed more to support or replace state institutions. Thus, non-profit organizations are able to operate effectively and provide various services even in limited economic conditions, identifying and filling the available regional niches. Finally, crime and the number of protected documents (including patents) do not seem to determine GRP in this estimation. The explanatory power of the whole model is high, which is, in general, usual for such specifications of time-series models.

In Est. 2 the results are presented of a random effects model, which is of less statistical quality than that of the model with fixed effects. As in the fixed effects model, the estimation again exhibits significant coefficients for the variables 


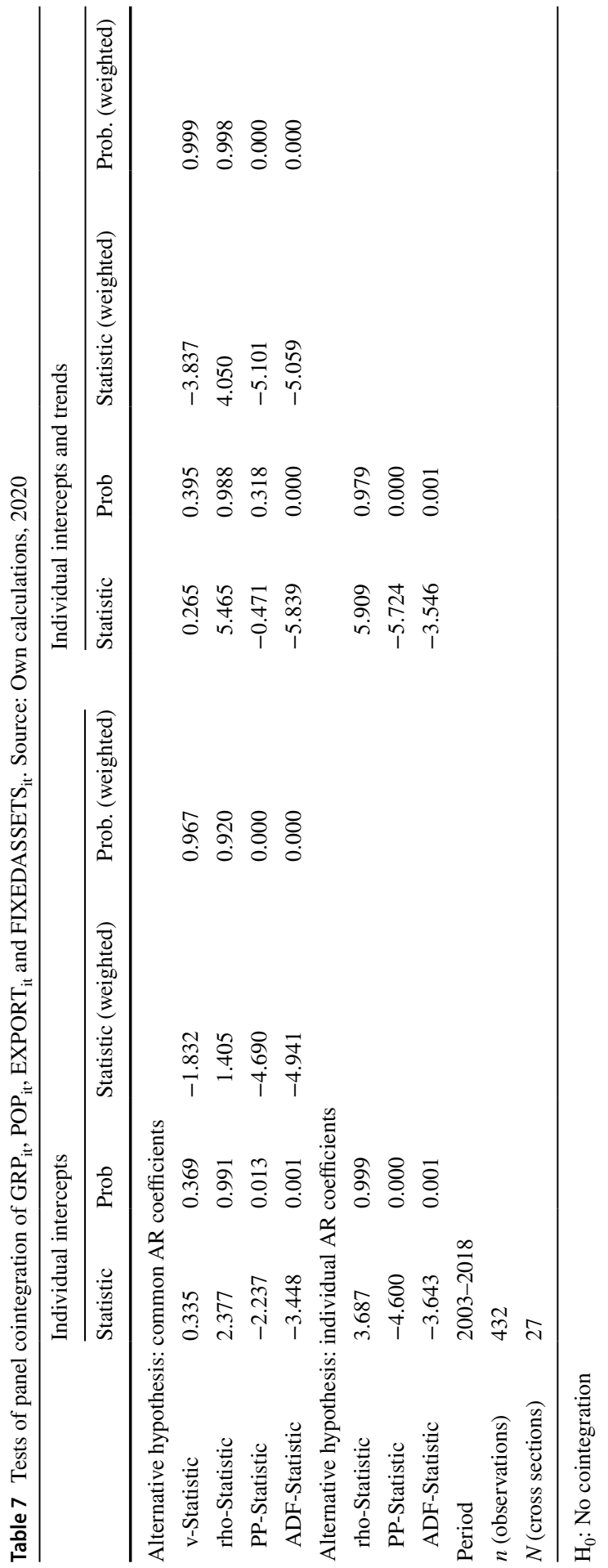




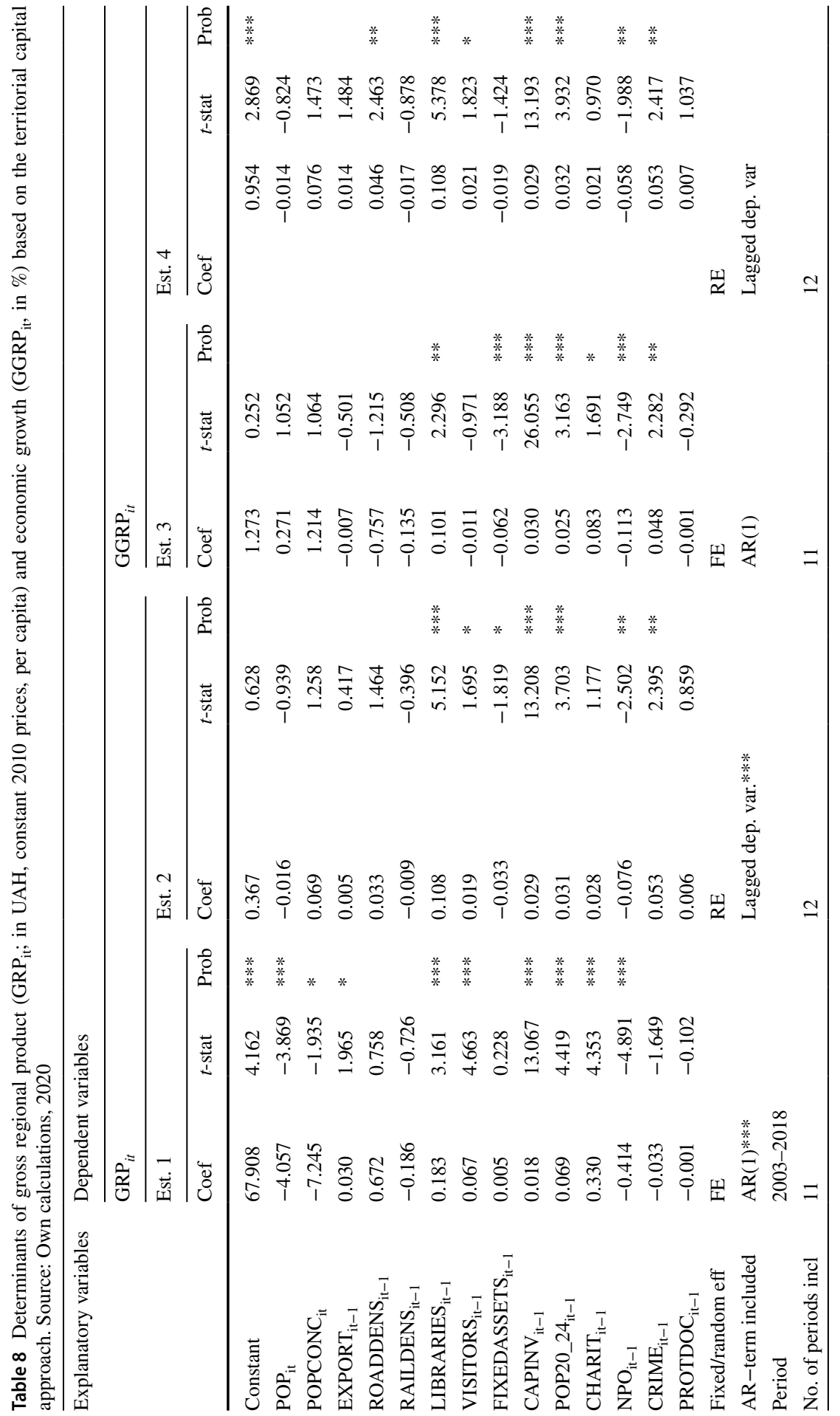




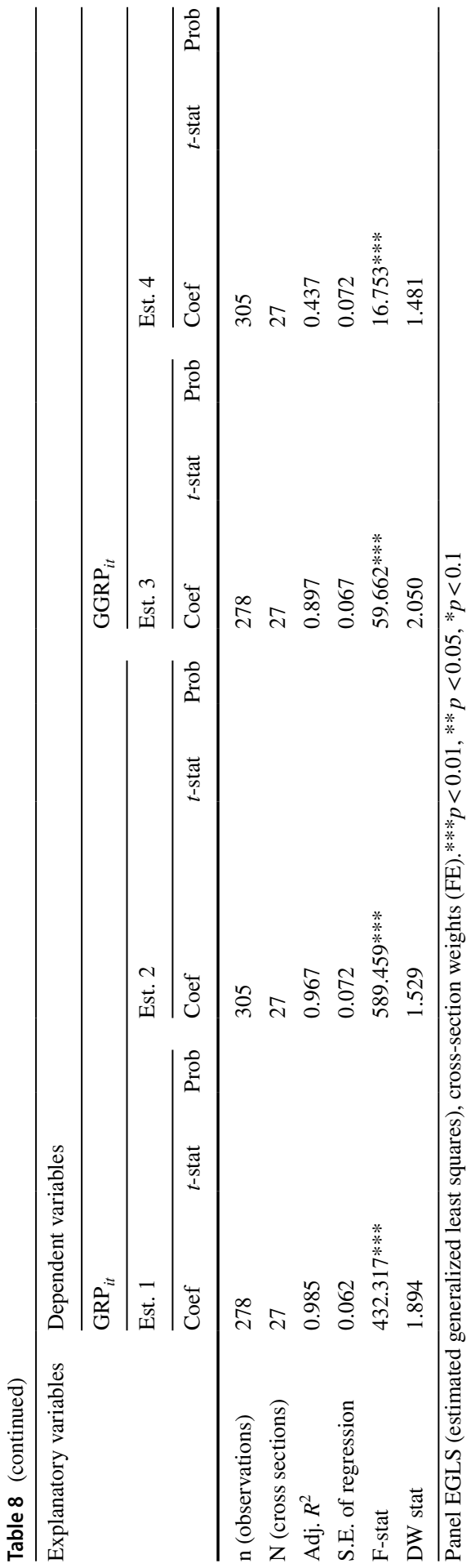


denoting, e.g., the number of visitors, capital investments, the age of the population, and the number of charity organizations. However, the general population variables become insignificant. The extent to which crime is problematic seems to be a moderately significant explanatory variable. ${ }^{2}$ In the comparison of Est. 1 and Est. 2, the results suggest that the fixed effects model of Est. 1 seems to be more robust.

The economic growth $\left(\mathrm{GGRP}_{\text {it }}\right)$ is tested in Est. 3 and 4 of Table 8. The explanatory power of the estimations is generally lower compared to the estimations described above, as expected. The fixed effects model in Est. 3 includes variables that are determining the regional income as well, such as the number of libraries (per capita), capital investments, the age structure of the population, and the number of non-profit organizations. However, the values of the fixed assets exhibit a negative correlation with regional growth, which can be reasonably argued by the growth rate being higher-ceteris paribus - in regions with a catch-up process, starting at lower levels of infrastructure and regional income. Similar to Est. 2, the number of crimes is positively correlated with economic growth. This may either be interpreted in terms of a lower starting point of economic development, or in regard to the volume of illegal transactions in times of rapid economic growth. Both interpretations, however, would warrant a further investigation, and point to institutional and governance problems in Ukraine.

Est. 4 of Table 8 presents the results of a random effects estimation. While some of the explanatory variables are significant as well, and basically exert a similar influence on economic growth, the road density seems to influence $\mathrm{GGRP}_{\text {it }}$ as an additional explanatory variable. However, the explanatory power of the random effects model is again less than that of the fixed effects model.

As a further set of estimations testing the territorial capital approach, Table 9 presents both a fixed and a random effects model for the level of employment (measured as a ratio of employment to the total population). Est. 5 supports the existence of a positive correlation of cultural capital (e.g., libraries), and the age structure of the population, with economic development. However, a number of interesting signs of the estimated coefficients can be detected. First of all, it seems that the variables that denote a measure of productivity (e.g., the number of patents) are negatively correlated with employment. Second, the number of crimes exerts a negative influence on employment. The latter result suggests that-while illegal activities and transactions lead to higher per-capita income-employment as recorded in official statistics is negatively influenced by crimes.

The random effects model presented in Est. 6 is, again, of lesser statistical quality than the fixed effects model, and shows some counter-intuitive correlations between the explanatory variables and the level of employment.

In the appendix to this paper (see Table 10), the results of additional fixed effects models are presented for the regional indicators of per-capita income

\footnotetext{
${ }^{2}$ The size of the shadow economy, and the number of crimes, are usually interpreted as indicators of the strength of governance and robustness of institutions facilitating increased income and economic development. However, the size of an economy measured by GDP has also been found to correlate with illegal transactions originating from crimes in gravity models ascertaining illegal money flows (cf. Ferwerda et al. 2020).
} 
Table 9 Determinants of employment (EMPL $\mathrm{it}_{\mathrm{it}}$; employment ratio to total population). Source: Own calculations, 2020

\begin{tabular}{|c|c|c|c|c|c|c|}
\hline \multirow[t]{3}{*}{ Explanatory variables } & \multicolumn{6}{|l|}{$\mathrm{EMPL}_{i t}$} \\
\hline & \multicolumn{3}{|l|}{ Est. 5} & \multicolumn{3}{|l|}{ Est. 6} \\
\hline & Coef & $t$-stat & Prob & Coef & $t$-stat & Prob \\
\hline Constant & 2.427 & 0.129 & & 2.73 & 3.151 & $* * *$ \\
\hline $\mathrm{POP}_{\text {it }}$ & 1.423 & 1.337 & & -0.064 & -1.527 & \\
\hline $\mathrm{POPCONC}_{\mathrm{it}}$ & -1.503 & -0.266 & & 0.186 & 1.337 & \\
\hline EXPORT $_{\text {it-1 }}$ & 0.021 & 0.626 & & 0.069 & 3.075 & $* * *$ \\
\hline ROADDENS $_{\text {it-1 }}$ & -3.311 & -1.950 & $*$ & 0.020 & 0.395 & \\
\hline RAILDENS $_{\text {it-1 }}$ & 1.224 & 2.065 & $* *$ & 0.021 & 0.394 & \\
\hline LIBRARIES $_{\mathrm{it}-1}$ & 0.559 & 3.009 & $* * *$ & 0.224 & 4.414 & $* * *$ \\
\hline VISITORS $_{\mathrm{it}-1}$ & 0.068 & 2.099 & $* *$ & 0.174 & 6.662 & $* * *$ \\
\hline FIXEDASSETS $_{\mathrm{it}-1}$ & -0.033 & -0.665 & & 0.033 & 0.939 & \\
\hline CAPINV $_{\text {it }-1}$ & -0.002 & -0.789 & & -0.011 & -2.184 & $* *$ \\
\hline POP20_24 $4_{\text {it }-1}$ & 0.08 & 3.05 & $* * *$ & 0.053 & 2.698 & $* * *$ \\
\hline CHARIT $_{\text {it-1 }}$ & -0.005 & -0.031 & & -0.078 & -1.353 & \\
\hline $\mathrm{NPO}_{i t-1}$ & 0.12 & 0.798 & & -0.16 & -2.281 & $* *$ \\
\hline CRIME $_{\text {it-1 }}$ & -0.197 & -4.162 & $* * *$ & 0.133 & 2.608 & $* * *$ \\
\hline PROTDOC $_{\mathrm{it}-1}$ & -0.041 & -2.605 & $* * *$ & 0.021 & 1.226 & \\
\hline Fixed/random eff & $\mathrm{FE}$ & & & $\mathrm{RE}$ & & \\
\hline AR-term included & $\operatorname{AR}(1) * * *$ & & & Lagged dep. var.*** & & \\
\hline Period & 2003-2018 & & & & & \\
\hline No. of periods incl & 11 & & & 12 & & \\
\hline n (observations) & 278 & & & 305 & & \\
\hline $\mathrm{N}$ (cross sections) & 27 & & & 27 & & \\
\hline Adj. $R^{2}$ & 0.902 & & & 0.699 & & \\
\hline S.E. of regression & 0.124 & & & 0.156 & & \\
\hline F-stat & $63.169 * * *$ & & & $48.152 * * *$ & & \\
\hline DW stat & 1.760 & & & 1.333 & & \\
\hline
\end{tabular}

Panel EGLS (estimated generalized least squares), cross-section weights (FE). $* * * p<0.01, * * p<0.05$, $* p<0.1$

$\left(\mathrm{GRP}_{\mathrm{it}}\right)$ and economic growth $\left(\mathrm{GGRP}_{\mathrm{it}}\right)$. Without going into detail here, owing to limitations of space, some additional channels of effects may be detected:

- The origin of capital investments (local governments and banks) seems to have a small effect on regional development.

- Perceived corruption, and the number of graduates in a region, are not significant predictors of income and economic growth. 
- Finally, visitors staying overnight seem to be correlated to regional income (GRP).

\section{Discussion, summary and conclusions}

According to our findings, the elements of territorial capital have different degrees of influence on the economic performance of Ukrainian regions. The research results show that people and their activities (directly or indirectly, i.e., through human capital and cultural capital) largely determine the gross regional product of each region (level of GRP). The results also indicate that capital investments and the number of charities have a substantial positive influence on regional per-capita GRP, while non-profit organizations are negatively correlated with its level.

A somewhat different situation is observed regarding the influence of chosen variables on GRP growth. In contrast to the previous case, we do not detect any influence of the size and density of the population in regard to the increase of GRP. However, similar to regional per-capita GRP, there is a significantly positive impact of the share of the population aged 20-24, and of capital investments on regional growth. Besides, there is a negative correlation of fixed assets and charity and nonprofit organizations with the rise of GRP.

The influence of the size and density of population is not found to be significant in regard to the level of employment. The results also indicate that the share of the young population and the number of libraries have a significant positive impact on the employment ratio. At the same time, the strong negative effect of patents and crimes on employment has been identified.

Thus, it can be concluded that human capital has the highest positive influence on the economic performance of Ukrainian regions among the elements of territorial capital, as considered in this paper. It is also found that there is a favourable effect of cultural capital, as well as (private) physical capital in some cases, on regional development. The obtained results indicate that transport infrastructure only has a limited influence, or no influence at all, on the economic state of regions. While cultural and physical capital exert the expected influence on regional GDP, transport infrastructure is of less importance as the variations between regions and over time are not large enough. While institutional and relational and social capital demonstrate mixed effects on the regional economy, entrepreneurial capital seem to have no detectable influence on the regional economic development.

This paper has a number of limitations that reduce the validity of the empirical estimations. On the one hand, there are numerous problems with the reliability of the data. For instance, data on those regions that are affected by military conflicts are not available, or are not reliable. On the other hand, the availability of the data poses a restriction to the application of the full conceptual model of the territorial 
capital approach according to, e.g., Camagni and Capello (2008) or Tóth (2017). Some of the estimations may also suffer from multi-collinearity since the single elements of the territorial capital approach are not independent explanatory variables, but are determined in joint (policy) frameworks. However, our empirical estimations indicate that some of the elements of territorial capital are in fact correlated with the development of regions in Ukraine.

From a methodological point of view, the empirical framework chosen for this paper may also lack the option to simultaneously estimate bidirectional influcenes of the various variables about the regional development in Ukraine. For instance, fixed assets may also be determined by GDP growth in an endogenous growth model. Corruption, the number of patents, and NGOs, might also be influenced by economic development.

The territorial capital approach presents an opportunity to analyze the strengths of these regions in Ukraine and weaknesses in detail, and to improve the understanding of developments of the regional economy. Besides the rebuilding of the economies affected by the military conflicts, the results of this paper bear a number of regional and economic policy conclusions, for instance, in regard to the importance of the elements of the territorial capital of the regions. The results suggest that there is no clear-cut effect of the territorial capital approach on regional development. However, the approach enriches the existing models of regional development, especially those emphasizing the importance of the supply-side of the economy.

The results of this paper also point to the importance of public policies in supporting these elements of territorial capital. These policies include the provision and implementation of robust legal frameworks to increase trust and to reduce corruption. Ukraine has made various efforts to improve governance structures. However, the indices of corruption are still worrisome.

In addition, the support of educational efforts and the institutions of the civil society, and the promotion of local (municipal) investments in the sense of a foundational economy are further important fields of economic policies. In regard to the effects of the military conflicts in the Eastern parts of Ukraine, the results once again show that such conflicts destroy the foundations of economic development by degrading both physical as well as intangible teritorial capital.

\section{Appendix}

See Table 10 . 


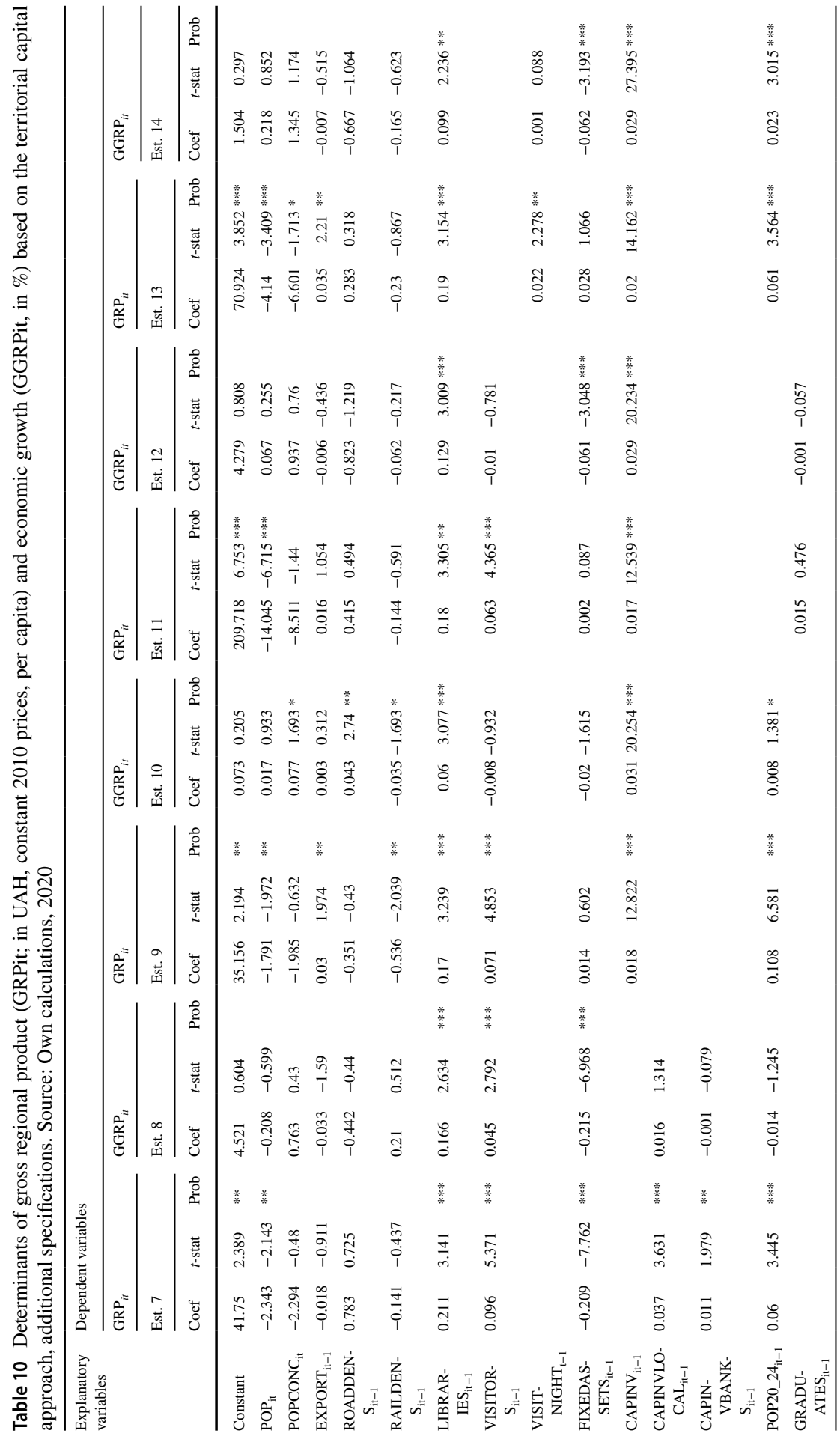




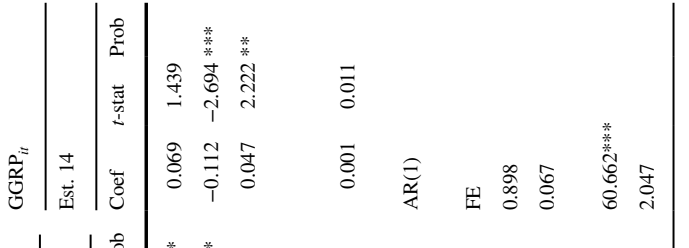

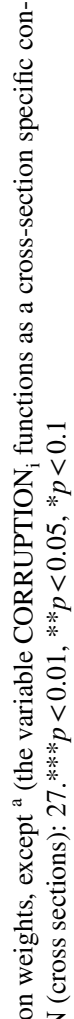

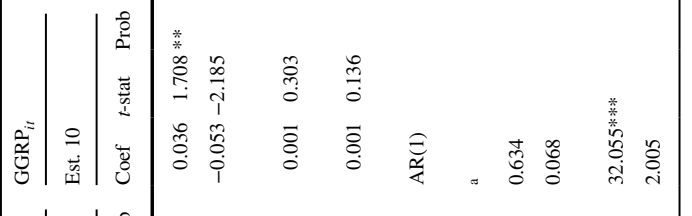

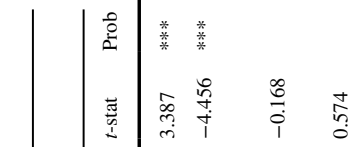

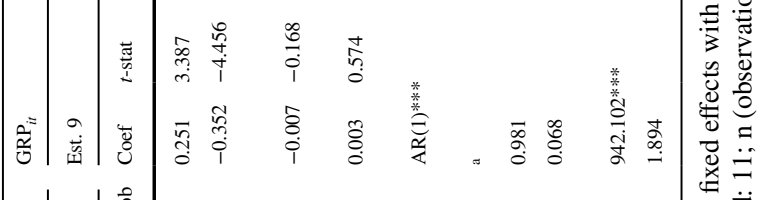

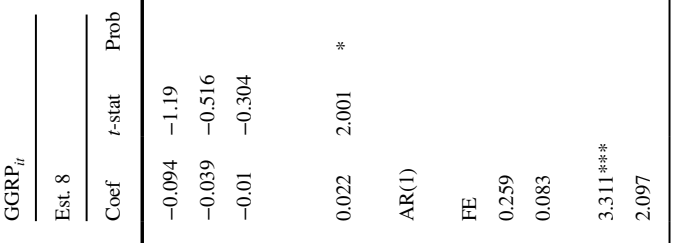

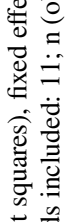

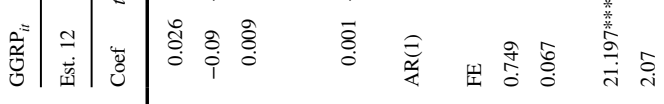

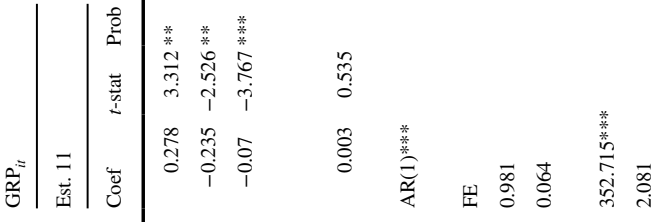

吾

至

范苛

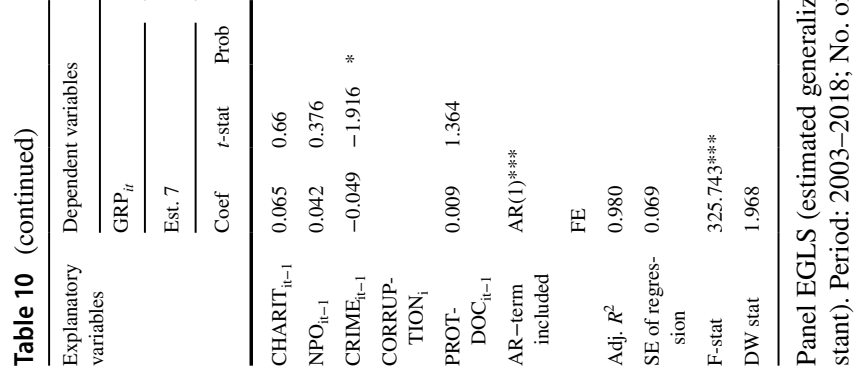


Acknowledgements The authors thank the anonymous reviewers and the editors who provided many helpful suggestions for substantial improvements of the paper. All errors are, of course, the responsibility of the authors.

Funding Open access funding provided by TU Wien (TUW).

\section{Declarations}

Conflict of interest The authors declare that there is no conflict of interest.

Open Access This article is licensed under a Creative Commons Attribution 4.0 International License, which permits use, sharing, adaptation, distribution and reproduction in any medium or format, as long as you give appropriate credit to the original author(s) and the source, provide a link to the Creative Commons licence, and indicate if changes were made. The images or other third party material in this article are included in the article's Creative Commons licence, unless indicated otherwise in a credit line to the material. If material is not included in the article's Creative Commons licence and your intended use is not permitted by statutory regulation or exceeds the permitted use, you will need to obtain permission directly from the copyright holder. To view a copy of this licence, visit http://creativecommons.org/licen ses/by/4.0/.

\section{References}

Bachtrögler J, Fratesi U, Perucca G (2019) The influence of the local context on the implementation and impact of EU cohesion policy. Reg Stud 54:21-34. https://doi.org/10.1080/00343404.2018. 1551615

Barzotto M, Corò G, Volpe M (2016) Territorial capital as a company intangible: exploratory evidence from ten Italian multinational corporations. J Intellect Cap 17(1):148-167. https://doi.org/ 10.1108/JIC-09-2015-0077

Benassi F, D'Elia M, Petrei F (2021) The "meso" dimension of territorial capital: evidence from Italy. Reg Sci Policy Pract 13(1):159-175. https://doi.org/10.1111/rsp3.12365

Camagni R (2008) Regional competitiveness: towards a concept of territorial capital. In: Camagni R, Capello R, Chizzolini B, Fratesi U (eds) Modelling regional scenarios for the Enlarged Europe. Springer, Berlin, pp 33-48

Camagni R, Capello R (2008) Territorial capital and regional competitiveness: theory and evidence. Studies in Regional Science 39(1):19-39. https://doi.org/10.2457/srs.39.19

Capello R (2007) A forecasting territorial model of regional growth: the MASST model. Ann Regional Sci 41(4):753-787. https://doi.org/10.1007/s00168-007-0146-2

Council of the European Union (2020) EU restrictive measures in response to the crisis in Ukraine. Council of the European Union, Brussels (https://www.consilium.europa.eu/en/policies/sanct ions/ukraine-crisis/. Accessed July 2nd, 2021

Dodescu A-O, Botezat E-A, Costăngioară A, Bolos M-I (2018) An exploratory analysis of the territorial capital and economic growth: Evidence from Romania. Econ Comput Economic Cybern Studies Res 52(4):95-112. https://doi.org/10.24818/18423264/52.4.18.07

Fábián A, Tóth BI (2014) Which attributes of culture can we measure? The case of Hungarian microregions. Int J Global Environ Issues 13(2-4):294-307. https://doi.org/10.1504/IJGENVI.2014. 064499

Ferwerda Jv. Saase, A., Unger, B, Getzner M (2020) Estimating money laundering flows with a gravity model-based simulation. Sci Rep 10:18552. https://doi.org/10.1038/s41598-020-75653-X

Fratesi U, Perucca G (2014) Territorial capital and the effectiveness of cohesion policies: an assessment for CEE regions. Investigciones Regionales 29:165-191

Fratesi U, Perucca G (2019) EU regional development policy and territorial capital: a systemic approach. Pap Reg Sci 98(1):265-281. https://doi.org/10.1111/pirs.12360

Fratesi U, Perucca G (2020) EU Regional policy effectiveness and the role of territorial capital. In: Della Torre S, Cattaneo S, Lenzi C, Zanelli A (eds) Regeneration of the Built Environment from 
a Circular Economy Perspective. Research for Development. Springer, Cham, pp 29-37. https:// doi.org/10.1007/978-3-030-33256-3_4

Getzner M, Moroz S (2020) Regional development and foreign direct investment in transition countries: a case-study for regions in Ukraine. Post-Communist Econ 32(6):813-832. https://doi.org/ $10.1080 / 14631377.2020 .1745564$

Ilko Kucheriv Democratic Initiatives foundation (2018) One out of three Ukrainians ready to join organized counteraction to corruption. https://dif.org.ua/en/article/one-out-of-three-ukrainiansready-to-join-organized-counteraction-to-corruption

Jóna G (2015a) Determinants of Hungarian sub-regions' territorial capital. Euro Spatial Res Policy 22(1):101-119. https://doi.org/10.1515/esrp-2015-0019

Jóna G (2015b). New trajectories of the Hungarian regional development: balanced and rush growth of territorial capital. Regional Stat 5(1):121-136. https://doi.org/10.15196/RS05107

Lo Cascio I, Mazzola F, Epifanio R (2019) Territorial determinants and NUTS 3 regional performance: a spatial analysis for Italy across the crisis. Pap Reg Sci 98(2):641-677. https://doi.org/ 10.1111/pirs. 12372

Mazzola F, Lo Cascio I, Epifanio R, Di Giacomo G (2018) Territorial capital and growth over the Great Recession: a local analysis for Italy. Ann Reg Sci 60(2):411-441. https://doi.org/10.1007/ s00168-017-0853-2

Morretta V (2021) Territorial capital in local economic endogenous development. Reg Sci Policy Pract 13(1):103-119. https://doi.org/10.1111/rsp3.12317

Perucca G (2014) The role of territorial capital in local economic growth: evidence from Italy. Eur Plan Stud 22:537-562. https://doi.org/10.1080/09654313.2013.771626

Romão J, Neuts B (2017) Territorial capital, smart tourism specialization and sustainable regional development: experiences from Europe. Habitat Int 68:64-74. https://doi.org/10.1016/j.habitatint.2017. 04.006

Tóth BI (2017) Territorial capital - a fuzzy policy-driven concept: context, issues, and perspectives. EUROPA XXI 33:5-19. https://doi.org/10.7163/Eu21.2017.33.1

Welfe W (2013) The models of the Middle and East European Countries. Adv Stud Theoret Appl Econometrics 47:123-190. https://doi.org/10.1007/978-3-642-34468-8_9

Weyerstrass K (2008) Economic policies on Slovenia's road to the euro area. Econ Syst 32:92-102. https://doi.org/10.1016/j.ecosys.2007.09.003

Weyerstrass K, Haber G, Neck R (2001) SLOPOL1: A macroeconomic model for Slovenia. Int Adv Econ Resources 7:20-37. https://doi.org/10.1007/BF02296589

Publisher's Note Springer Nature remains neutral with regard to jurisdictional claims in published maps and institutional affiliations. 